\title{
PENGARUH JENIS TEH TERHADAP KARAKTERISTIK TEH KOMBUCHA
}

\author{
Ketut Ita Purnami ${ }^{1)}$, A.A.G.N. Anom Jambe ${ }^{2)}$, Ni Wayan Wisaniyasa ${ }^{2)}$ \\ ${ }^{1)}$ Mahasiswa Jurusan Ilmu dan Teknologi Pangan, Fakultas Teknologi Pertanian, Universitas Udayana \\ ${ }^{2)}$ Dosen Jurusan Ilmu dan Teknologi Pangan, Fakultas Teknologi Pertanian, Universitas Udayana
}

Email: itapurnami@ymail.com

\begin{abstract}
This study aims to know the influence of tea type on the characteristics of kombucha tea and determine the kind of tea that can produce kombucha tea with the best characteristics. This study used Completely Randomized Design (CRD) with the treatment of four types of tea were white tea, green tea, black tea and mixed tea (white tea, green tea and black tea). Each treatment was repeated four times to obtain 16 experimental units. The result of research showed that the best kombucha tea was white tea with characteristics: antioxidant capacity 807.86 ppm GAEAC, total acid 3.58\%, pH 4.14, total dissolved solids $10.00^{\circ}$ Brix, and total sugar $2.08 \mathrm{mg} / 100 \mathrm{~g}$, color (hedonic) rather like, aroma (hedonic) neutral, aroma (scores) kinda typical kombucha tea, taste (hedonic) neutral, taste (scores) tasted kombucha tea, overall acceptance rather like.
\end{abstract}

Keywords: kind of tea, kombucha, characteristics

\section{PENDAHULUAN}

Teh telah dikenal luas sebagai minuman yang baik untuk kesehatan (Hartoyo, 2003). Negeri Tiongkok menjadi tempat lahirnya teh, mereka menikmati rasa yang menyenangkan dari sari daun teh dan mulai dijadikan sebagai minuman. Tapi dalam sejarah Bali, jamur kombucha sudah ada sejak zaman kuno. Di Bali jamur kombucha pertama kali dikenalkan oleh Putri Kang Cing Wie asal Cina yang datang ke Pulau Bali. Teh kombucha dapat diperoleh dengan memeram larutan teh manis yang ditambahkan jamur kombucha. Jamur kombucha penghasil cairan kombucha adalah campuran dari beberapa mikroba berupa bakteri dan ragi (Hartoyo, 2003). Di Indonesia, sampai saat ini belum terdapat industri yang memproduksi dan menjual teh kombucha secara luas. Oleh karena itu, potensi pengembangan teh kombucha sangat besar.
Adapun jenis-jenis teh yang dikenal antara lain; teh putih, teh hijau, teh hitam. Teh putih saat diseduh warna air hanya sedikit berubah menjadi kekuningan. Teh hijau diolah tanpa proses fermentasi (oksidasi enzimatik), teh hitam mengalami proses fermentasi. Keunggulan teh kombucha dibandingkan cairan teh biasa adalah kandungan asam-asam organik dan beberapa senyawa seperti vitamin dan asam amino. Hasil penelitian yang dilakukan oleh Purwaning (2010) dan Rahayu (2005) menggunakan teh kombucha terhadap tikus putih menunjukkan penurunan kadar kolesterol. Pembuatan teh kombucha yang dibuat dari berbagai variasi daun yaitu daun salam, daun jambu, daun sirih, daun sirsak, daun kopi, dan daun teh, menyatakan bahwa teh kombucha terbaik adalah yang terbuat dari daun teh, karena tannin yang terkandung di dalam daun teh paling tinggi sehingga 
mempengaruhi tingkat antioksidan media pertumbuhan jamur kombucha (Suhardini, 2015).

Seluruh jenis teh yang ada berasal dari satu jenis tanaman teh melalui proses pengolahan tertentu yang akan memberikan ciri khas pada teh tersebut. Proses pengolahan teh menjadi teh kombucha dengan perbedaan konsentrasi teh, konsentrasi stater (jamur kombucha), lama fermentasi dan jenis teh dapat mengakibatkan adanya perbedaan rasa, aroma, komposisi dan jumlah kandungan kimia yang terkandung didalamnya. Berdasarkan latar belakang tersebut, maka perlu dilakukan penelitian tentang pengaruh jenis teh terhadap karakteristik teh kombucha. Tujuan dari penelitian ini adalah mengetahui pengaruh jenis teh terhadap karakteristik teh kombucha dan mengetahui jenis teh yang dapat menghasilkan teh kombucha dengan karakteristik terbaik.

\section{METODE PENELITIAN}

\section{Tempat dan Waktu Penelitian}

Penelitian ini dilaksanakan di Laboratorium Pengolahan Pangan dan Laboratorium Analisis Pangan, Program Studi Ilmu dan Teknologi Pangan, Fakultas Teknologi Pertanian, Gedung Agrokomplek Universitas Udayana, Jalan P.B. Sudirman, Denpasar, Bali. Penelitian ini dilakukan pada bulan November 2016 - Januari 2017.

\section{Alat dan Bahan}

Alat-alat yang digunakan dalam melaksanakan penelitian ini, antara lain : pengaduk teh kayu, toples kaca, penyaringan plastik, botol kaca, Waskom kaca, kain kasa, karet gelang, sendok kayu, timbangan analitik (Shimodzu ATY 224), pH meter, kertas saring, tabung reaksi (Pyrex), corong plastik, plastik 1 $\mathrm{kg}$, kulkas, vortex, handrefraktometer, waterbath dan soxhlet (Sybron 2200).

Adapun bahan yang digunakan dalam melaksanakan penelitian ini, antara lain: teh putih, teh hijau, dan teh hitam, teh campuran dicampur sendiri (teh putih, teh hijau, teh hitam) yang diperoleh dari (Toko Brew Me merk Bali Tea Gallery). Gula pasir (merk Gulaku) yang diperoleh dari (Toko Karunia Dewata), air diperoleh dari (Minimarket 828) dan stater kombucha diperoleh dari (Jalan Danau Tamblingan, Sanur, Bali). Bahan kimia yang di gunakan dalam melakukan analisis meliputi aquades, asam galat, methanol, DPPH, indikator phenolphthalein (PP), nelson A, nelson B, Arsenomolibdat, $\mathrm{HCl} 4 \mathrm{~N}, \mathrm{NaOH}$ $50 \%$, standar glukosa dan $\mathrm{NaOH} 0,1 \mathrm{~N}$.

\section{Rancangan Penelitian}

Penelitian ini menggunakan Rancangan Acak Lengkap (RAL) dengan perlakuan jenis teh yang digunakan, yaitu : $\mathrm{A} 1=$ Teh putih 50 gram, $\mathrm{A} 2=$ Teh Hijau 50 gram, A3 = Teh Hitam 50 gram, A4 = Teh Campuran dari teh putih 16,6 gram, teh hijau 16,6 gram dan teh hitam 16,6 gram. Masing-masing perlakuan diulang sebanyak 4 kali sehingga diperoleh 16 
unit percobaan. Data yang diperoleh kemudian dianalisis dengan sidik ragam dan apabila terdapat pengaruh perlakuan dilanjutkan dengan uji Duncan (Gomes dan Gomes, 1995).

\section{Variabel yang Diamati}

Variabel yang diamati pada penelitian ini meliputi : kapasitas antioksidan (Chan et al., 2007 dalam Almey et al., 2010), total asam (Sudarmadji dkk, 1984), derajat keasaman $(\mathrm{pH})(\mathrm{AOAC}, 1995)$, total padatan terlarut (TPT) (AOAC, 1995), kadar gula (Nelson, 1944), dan evaluasi sensori (Septyaningsih et al., 2010).

\section{Pelaksanaan Penelitian}

\section{Pembuatan Teh Kombucha}

Persiapan bahan-bahan yang digunakan dalam pembuatan teh kombucha yaitu teh putih, teh hijau, teh hitam, air, dan gula pasir. Bahan yang digunakan kemudian ditimbang sesuai dengan formulasinya. Proses pembuatan teh kombucha dapat dilihat pada Gambar 1.

Pembuatan teh kombucha dimulai dengan disiapkan panci yang berisi air dan gula dipanaskan menggunakan kompor dengan perbandingan air dan gula ( 1 liter : 150 gram ) yang menghasilkan larutan gula. Larutan gula yang telah dipanaskan ditambahkan daun teh sesuai perlakuan sebanyak 50 gram lalu diaduk, dilakukan pemanasan 10 menit dan didinginkan kemudian disaring untuk menghilangkan ampas tehnya maka, dihasilkan ekstrak teh manis $750 \mathrm{ml}$ yang telah disaring. Setelah itu, dilanjutkan dengan penuangan pada toples kaca dan ditambahkan stater kombucha $10 \%$ (padatan stater $5 \%$ dan cairan stater 5\%) lalu difermentasi pada suhu ruang selama 12 hari. Setelah 12 hari, dilakukan pemisahan minuman teh kombucha dengan stater kombucha. 


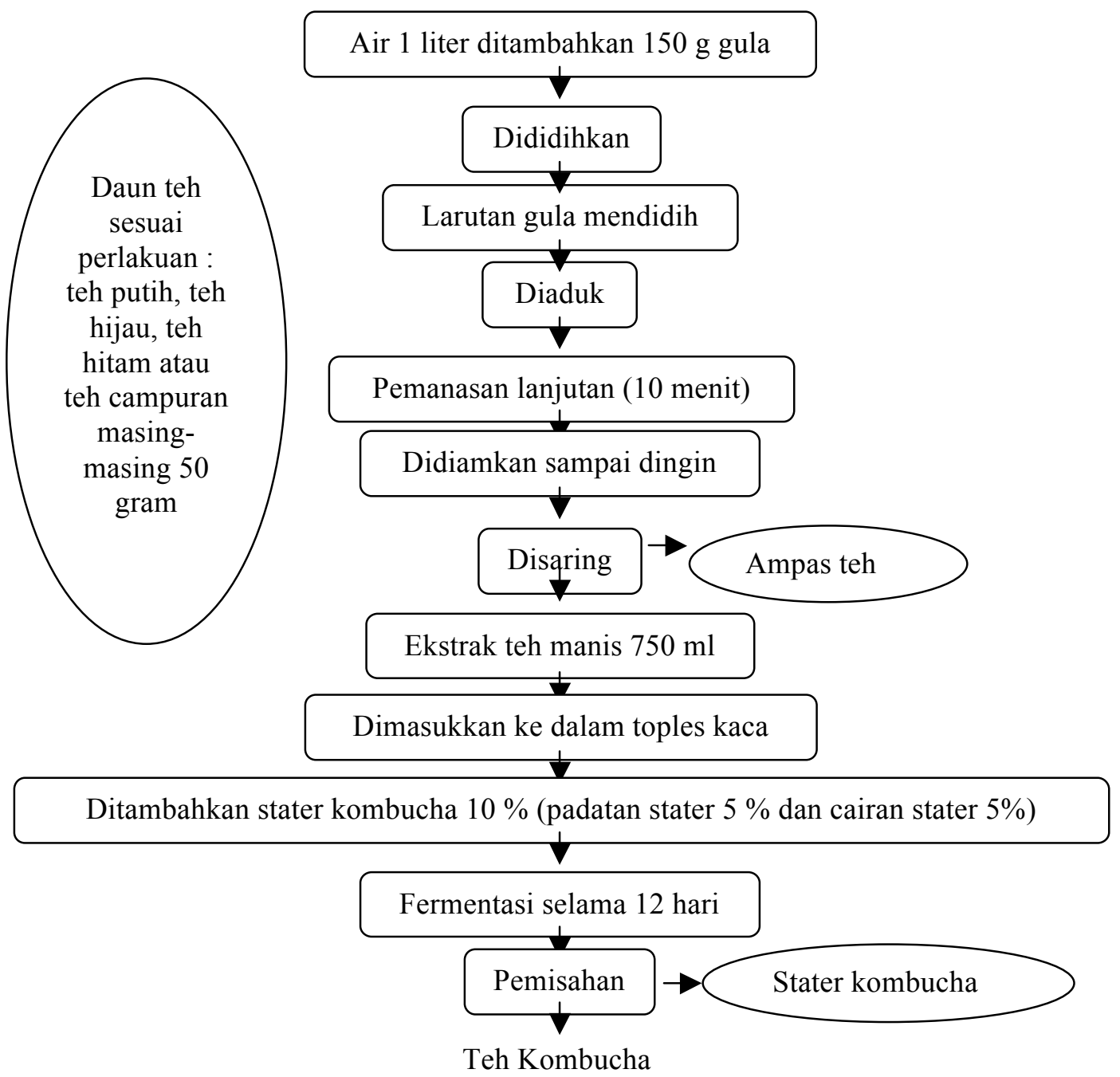

Gambar 1. Diagram Alir Proses Pembuatan Teh Kombucha (Rinihapsari dan Catur, 2008 yang dimodifikasi)

\section{HASIL DAN PEMBAHASAN}

Hasil analisis kapasitas antioksidan, total asam, $\mathrm{pH}$, total padatan terlarut, dan total gula teh kombucha disajikan pada Tabel 1.

\section{Kapasitas Antioksidan}

Hasil analisis ragam menunjukkan bahwa jenis teh berpengaruh sangat nyata $(\mathrm{P}<0,01)$ terhadap kapasitas antioksidan teh kombucha. Tabel 1 menunjukkan kapasitas antioksidan teh kombucha berkisar antara 793,64 ppm
GAEAC sampai dengan 807,86 ppm GAEAC. Kapasitas antioksidan tertinggi diperoleh dari teh kombucha yang menggunakan jenis teh putih yaitu 807,86 ppm GAEAC dengan kapasitas antioksidan terendah terdapat pada teh kombucha berbahan teh hitam yaitu 793,64 ppm GAEAC.

Tabel 1 menunjukkan kapasitas antioksidan teh hitam paling rendah dibandingkan kapasitas antioksidan teh putih, 
teh hijau dan teh campuran. Penelitian Lee dan Hoo (2001) mengungkapkan bahwa kapasitas antioksidan teh dapat dipengaruhi oleh komposisi dan konsentrasi senyawa antioksidan yang dikandung teh. Pucuk pertama daun teh, kandungan katekinnya lebih tinggi dibanding daun teh yang lainnya. Teh putih ini memiliki kandungan katekin yang tinggi karena semakin muda daun akan semakin tinggi pula kadar katekinnya. Itu sebabnya, kandungan katekin dalam teh putih dan teh hijau lebih banyak daripada teh hitam.

Tabel 1. Nilai Rata-Rata Kapasitas Antioksidan, Total Asam, pH, Total Padatan Terlarut, dan Total Gula Teh Kombucha.

\begin{tabular}{cccccc}
\hline \multirow{2}{*}{$\begin{array}{c}\text { Perlakuan } \\
\text { Teh Kombucha }\end{array}$} & $\begin{array}{c}\text { Kapasitas } \\
\text { Antioksidan } \\
\text { (ppm GAEAC) }\end{array}$ & $\begin{array}{c}\text { Asam } \\
(\%)\end{array}$ & $\mathrm{pH}$ & $\begin{array}{c}\text { Total Padatan } \\
\text { Terlarut } \\
(\text { TSS })\left({ }^{\circ} \mathrm{Brix}\right)\end{array}$ & $\begin{array}{c}\text { Total Gula } \\
(\mathrm{mg} / 100 \mathrm{~g})\end{array}$ \\
\hline A1 (teh putih) & $807,86 \mathrm{a}$ & $3,58 \mathrm{a}$ & $3,14 \mathrm{~b}$ & $10,00 \mathrm{a}$ & $2,08 \mathrm{a}$ \\
A2 (teh hijau) & $801,48 \mathrm{~b}$ & $3,26 \mathrm{~b}$ & $3,44 \mathrm{a}$ & $10,25 \mathrm{a}$ & $2,98 \mathrm{a}$ \\
A3 (teh hitam) & $793,64 \mathrm{~d}$ & $3,22 \mathrm{~b}$ & $3,42 \mathrm{a}$ & $9,75 \mathrm{a}$ & $3,13 \mathrm{a}$ \\
A4 (teh campuran) & $796,63 \mathrm{c}$ & $3,35 \mathrm{~b}$ & $3,37 \mathrm{a}$ & $9,75 \mathrm{a}$ & $2,89 \mathrm{a}$ \\
\hline
\end{tabular}

Keterangan : Nilai rata-rata yang diikuti oleh huruf yang berbeda pada kolom sama menunjukkan perbedaan sangat nyata $(\mathrm{P}<0,01)$.

\section{Total Asam}

Hasil analisis ragam menunjukkan bahwa jenis teh berpengaruh sangat nyata $(\mathrm{P}<0,01)$ terhadap total asam teh kombucha. Tabel 1 menunjukkan total asam teh kombucha berkisar antara $3,22 \%$ sampai dengan $3,58 \%$. Total asam tertinggi diperoleh teh kombucha berbahan teh putih yaitu $3,58 \%$, sedangkan total asam terendah diperoleh dari teh hitam yaitu $3,22 \%$.

Total asam pada teh kombucha menentukan cita rasa teh kombucha. Jenis teh yang berbeda pun mempengaruhi kadar total asam pada teh kombucha. Tabel 1 memperlihatkan bahwa semakin cepat fermentasi berlangsung total asam semakin meningkat. Semakin tinggi total asam, $\mathrm{pH}$ semakin turun. Menurut Wood dan Lass (1985) menyatakan bahwa asam asetat mencapai puncaknya setelah 5 sampai 6 hari kemudian turun. Naland (2004) menyatakan menambahkan, teh kombucha menghasilkan asam-asam organik antara lain asam glukoronat, asam asetat, asam glukonat, asam kondrotin sulfat, asam hyaluronik, asam hyaluronidase dan asam amino.

pH

Hasil analisis ragam menunjukkan bahwa jenis teh berpengaruh sangat nyata $(P<0,01)$ terhadap $\mathrm{pH}$ teh kombucha. Tabel 1 menunjukkan bahwa $\mathrm{pH}$ teh kombucha 
berkisar antara 3,14 sampai dengan 3,44. $\mathrm{pH}$ teh kombucha tertinggi diperoleh dari teh kombucha berbahan jenis teh hijau yaitu 3,44, sedangkan $\mathrm{pH}$ teh kombucha terendah diperoleh dari bahan teh putih yaitu 3,14 .

Tabel 1 menunjukkan semakin meningkat kandungan asam suatu bahan maka nilai $\mathrm{pH}$ akan semakin turun. $\mathrm{pH}$ teh kombucha paling rendah pada teh putih kemungkinan karena konsentrasi asam asetat yang paling tinggi dibuktikan dari nilai total asam yang paling tinggi. Penurunan $\mathrm{pH}$ dalam fermentasi akan mendukung kehidupan bakteri Acetobacter xylinum dalam starter kombucha untuk melangsungkan aktivitas metabolisme asam asetat yang terlarut akan terdisosiasi untuk melepaskan proton-proton bebas yang menurunkan $\mathrm{pH}$ larutan (Wistiana dan Zubaidah, 2015).

\section{Total Padatan Terlarut}

Hasil analisis ragam menunjukkan bahwa jenis teh tidak berpengaruh nyata $(\mathrm{P}>0,05)$ terhadap total padatan terlarut teh kombucha. Tabel 1 menunjukkan total padatan terlarut teh kombucha berkisar antara 9,75\% sampai dengan $10,25 \%$.

Total padatan terlarut adalah ukuran dari jumlah material yang dilarutkan dalam air.
Padatan terlarut yang terdiri dari karbohidrat yang larut dalam air yaitu gula-gula sederhana monosakarida dan disakarida. Bahan ini dapat mencakup karbonat, bikarbonat, klorida, sulfat, fosfat, nitrat, kalsium, magnesium, natrium, ion-ion organik. Pada dasarnya total padatan terlarut suatu bahan yang meliputi gula reduksi, gula non reduksi, asam-asam organik, pektin dan protein.

\section{Total Gula}

Hasil analisis ragam menunjukkan bahwa jenis teh tidak berpengaruh nyata $(\mathrm{P}>0,05)$ terhadap total gula teh kombucha yang dihasilkan. Mikroba membutuhkan gula sebagai sumber karbon. Gula pada media akan digunakan oleh mikroba sebagai nutrisi yang kemudian akan diubah menjadi alkohol, $\mathrm{CO}_{2}$ dan asam karbonat (Suprapti, 2003 dalam Silaban, 2005). Energi diperlukan untuk mempertahankan kehidupan stater kombucha dan untuk perkembangbiakan stater serta untuk pergerakan organisme yang bersifat motil. Menurut Rahayu dan Kuswanto (1987), total gula semakin menurun dikarenakan khamir (Saccharomyces cereviseae) menguraikan sukrosa menjadi alkohol sehingga kadar alkohol teh kombucha semakin meningkat. 


\section{Evaluasi Sensoris}

Evaluasi sensori teh kombucha dilakukan dengan uji hedonik terhadap warna, aroma, rasa, penerimaan keseluruhan dan uji skoring terhadap aroma, dan rasa. Nilai rata-rata penilaian sensoris terhadap karakteristik teh kombucha disajikkan pada Tabel 2.

Tabel 2. Nilai rata-rata penilaian sensoris terhadap karakteristik teh kombucha.

\begin{tabular}{ccccccc}
\hline \multirow{2}{*}{$\begin{array}{c}\text { Perlakuan } \\
\text { Teh Kombcha }\end{array}$} & Warna & \multicolumn{2}{c}{ Aroma } & \multicolumn{2}{c}{ Rasa } & $\begin{array}{c}\text { Penerimaan } \\
\text { Keseluruhan }\end{array}$ \\
\cline { 2 - 7 } & \multicolumn{2}{c}{ Hed } & Skor & Hed & Skor & Hed \\
\hline A1 (teh putih) & $4,60 \mathrm{c}$ & $4,00 \mathrm{a}$ & $3,40 \mathrm{a}$ & $4,40 \mathrm{ab}$ & $3.75 \mathrm{~b}$ & $4,50 \mathrm{~b}$ \\
A2 (teh hijau) & $5,60 \mathrm{ab}$ & $4,30 \mathrm{a}$ & $3,40 \mathrm{a}$ & $4,25 \mathrm{~b}$ & $3,80 \mathrm{~b}$ & $4,45 \mathrm{~b}$ \\
A3 (teh hitam) & $4,85 \mathrm{bc}$ & $4,30 \mathrm{a}$ & $3,55 \mathrm{a}$ & $3,75 \mathrm{~b}$ & $3,65 \mathrm{~b}$ & $4,35 \mathrm{~b}$ \\
A4 (teh campuran) & $5,95 \mathrm{a}$ & $4,85 \mathrm{a}$ & $3,80 \mathrm{a}$ & $5,20 \mathrm{a}$ & $4,30 \mathrm{a}$ & $5,45 \mathrm{a}$ \\
\hline
\end{tabular}

Keterangan : Nilai rata-rata yang diikuti oleh huruf yang berbeda pada kolom sama menunjukkan perbedaan yang nyata $(\mathrm{P}<0,01) ;$ Hed $=$ Hedonik, Skor $=$ Skoring

\section{Warna}

Hasil analisis ragam terhadap uji hedonik menunjukkan bahwa jenis teh berpengaruh sangat nyata $(\mathrm{P}<0,01)$ terhadap warna teh kombucha (uji hedonik). Tabel 2 menunjukkan bahwa nilai rata-rata tingkat kesukaan panelis terhadap warna teh kombucha berkisar antara 4,60 (agak suka) sampai dengan 5,95 (suka). Nilai rata-rata tertinggi diperoleh dari teh campuran yaitu 5,95 (suka), sedangkan nilai rata-rata terendah diperoleh dari teh putih yaitu 4,60 (agak suka).Winarno dalam Oryza (2006) mengatakan bahwa penilaian mutu bahan makanan yang umumnya bergantung pada beberapa faktor antara lain warna, aroma, rasa, penerimaan keseluruhan. Dimana teh kombucha putih memiliki warna khas teh putih yaitu putih keperakan, teh kombucha hijau memiliki warna khas teh hijau yaitu hijau keemasan. Teh kombucha hitam berwarna khas dari teh hitam yang memiliki warna merah dibandingkan teh hijau yaitu hijau keemasan dan teh kombucha campuran memiliki warna merah pekat hampir sama dengan warna teh kombucha hitam. Warna khas masing-masing teh berbeda karena terdapat perbedaan pada saat proses pengolahan pucuk teh tersebut.

\section{Aroma}

Berdasarkan uji hedonik, hasil analisis ragam menunjukkan bahwa jenis teh tidak berpengaruh nyata $(\mathrm{P}>0,05)$ terhadap aroma teh kombucha. Tabel 2 menunjukkan bahwa nilai rata-rata tingkat kesukaan panelis terhadap aroma teh kombucha berkisar antara 4,00 (netral) sampai dengan 4,85 (agak suka).Berdasarkan uji skoring, hasil analisis 
ragam menunjukkan bahwa jenis teh tidak berpengaruh nyata $(\mathrm{P}>0,05)$ terhadap aroma teh kombucha. Tabel 2 menunjukkan bahwa nilai rata-rata tingkat kesukaan panelis terhadap aroma teh kombucha berkisar antara 3,40 (agak tidak terasa teh kombucha) sampai dengan 3,80 (khas teh kombucha).

Aroma juga menjadi faktor penentu daya terima panelis(Khasanah, 2003). Aroma yang terdapat pada teh kombucha disebabkan karena adanya asam-asam organik dan aroma yang ditimbulkan pada daun teh itu sendiri. Aroma pada teh kombucha juga disebabkan oleh senyawa-senyawa volatil antara lain alkohol, asam asetat, dan asam-asam organik yang terbentuk sehingga menimbulkan aroma asam yang khas.

\section{Rasa}

Berdasarkan uji hedonik, hasil analisis ragam menunjukkan bahwa jenis teh berpengaruh sangat nyata $(\mathrm{P}<0,01)$ terhadap rasa teh kombucha. Tabel 2 menunjukkan bahwa nilai rata-rata tingkat kesukaan panelis terhadap rasa teh kombucha berkisar antara 3,75 (biasa) sampai dengan 5,20 (agak suka). Nilai rata-rata tertinggi diperoleh dari teh campuran yaitu 5,20 (agak suka), sedangkan nilai rata-rata terendah diperoleh dari teh hitam yaitu 3,75 (biasa).Berdasarkan uji skoring, hasil analisis ragam menunjukkan bahwa jenis teh berpengaruh nyata $(\mathrm{P}<0,05)$ terhadap rasa teh kombucha. Tabel 2 menunjukkan bahwa nilai rata-rata tingkat kesukaan panelis terhadap rasa teh kombucha berkisar antara
3,65 (terasa teh kombucha) sampai dengan 4,30 (terasa teh kombucha). Nilai rata-rata tertinggi diperoleh dari teh campur yaitu 4,30 (terasa teh kombucha), sedangkan nilai ratarata terendah diperoleh dari teh hitam yaitu 3,65 (terasa teh kombucha).

Tingkat kesukaan panelis terhadap rasa paling tinggi didapatkan dari jenis teh campuran dibandingkan jenis teh lainnya. Teh putih cenderung memiliki rasa manis dan lebih ringan pekatnya karena daun teh putih diambil dari pucuk paling muda dibandingkan dengan teh hijau yang memiliki rasa yang kuat dan teh hitam yang memiliki rasa pahit dan sepat.Rasa dari teh campuran merupakan hasil dari keseimbangan dari variasi sensasi rasa yang berasal dari gabungan teh putih, teh hijau dan teh hitam. Hal ini didukung oleh pendapat Chaturvedula dan Prakash (2011), rasa asing adalah rasa yang menyimpang dari rasa khas teh. Hasil teh campuran menghasilkan rasa asing berupa adanya sensasi rasa manis, serta rasa pahit yang cukup kuat yang merupakan karakteristik dari teh campuran dari gabungan teh putih, teh hijau dan teh hitam.

\section{Penerimaan Keseluruhan}

Hasil analisis ragam menunjukkan bahwa jenis teh berpengaruh nyata $(\mathrm{P}<0,05)$ terhadap penerimaan keseluruhan (uji hedonik) teh kombucha. Tabel 2 menunjukkan bahwa nilai rata-rata panelis terhadap penerimaan keseluruhan teh kombucha berkisar antara 4,35 (biasa) sampai dengan 5,45 (agak suka). Nilai rata-rata tertinggi diperoleh dari perlakuan teh 
campuran yaitu 5,45 (agak suka), sedangkan nilai rata-rata terendah diperoleh dari teh hitam yaitu 4,35 (biasa). Rata-rata dari penerimaan keseluruhan pada uji sensori menunjukkan kriteria yang berkisar dari biasa hingga agak suka. Penerimaan keseluruhan menunjukkan bahwa teh kombucha dapat diterima dengan cukup baik oleh panelis.

\section{KESIMPULAN DAN SARAN}

\section{Kesimpulan}

Berdasarkan penelitian ini dapat disimpulkan sebagai berikut:

1. Jenis teh berpengaruh sangat nyata terhadap kapasitas antioksidan, total asam, $\mathrm{pH}$, warna (uji hedonik) dan rasa (uji hedonik) serta berpengaruh tidak nyata terhadap total padatan terlarut, total gula, uji hedonik dan uji skoring aroma dan penerimaan keseluruhan.

2. Berdasarkan analisis karakteristik teh kombucha terbaik adalah yang berbahan baku teh putih dengan karakteristik kapasitas antioksidan 807,86 ppm GAEAC, total asam 3,58\%, pH 4,14, total padatan terlarut $10,00^{\circ}$ Brix, dan total gula $2,08 \mathrm{mg} / 100 \mathrm{~g}$, warna (hedonik) agak suka, aroma (hedonik) biasa, aroma (skoring) agak khas teh kombucha, rasa (hedonik) biasa, rasa (skoring) terasa teh kombucha, penerimaan keseluruhan agak suka.

\section{Saran}

1. Jenis teh yang terbaik untuk membuat teh kombucha adalah teh putih.
2. Perlu dilakukan penelitian untuk mengetahui umur simpan teh kombucha.

\section{DAFTAR PUSTAKA}

Almey, A. 2010. Total Phenolic Content and Primary Antioxidant Activity of Methanolic and Ethanolic Extract of Aromatic Plants Leaves. International Food Research Journal.: 17: 10771084.

AOAC. 1995. Official Methods of Analysis, $16^{\text {th }}$ ed. AOAC International. Gaithersbug. University of Maryland, USA.

Chaturvedula, V. S. dan I. Prakash. 2011. The Aroma, Taste, Color and Bioactive Constituents of Tea. Journal of Medicinal Plants Research.: 5(11): 2110-2124.

Gomes, K. A. dan A. A. Gomes. 1995. Prosedur Statistik untuk Penelitian Pertanian. UI Press. Jakarta.

Hartoyo, A. 2003. Teh dan Khasiatnya bagi Kesehatan. Kansius. Yogyakarta.

Khasanah, U. 2003. Formulasi Karakterisasi Fisiko-Kimia dan Organoleptik Produk Makanan Sarapan Ubi Jalar (Sweet Potato Flakes). Skripsi. Fakultas Teknologi Pertanian. Institut Pertanian Bogor, Bogor.

Lee, K. W. dan L. H. Joo. 2001. Antioxidant Activity of Black Tea vs. Green Tea. Department of Food Science and Technology. School of Agricultural Biotechnology. Seoul National University, Korea.

Naland, H. 2004. Kombucha Teh Ajaib Pencegah dan Penyembuh Aneka Penyakit. Agromedia Pustaka, Jakarta.

Nelson, N. 1944. A Photometric Adaptation of the Somogyi Method for the Determination of Glucose The Journal of Biological Chemistry. 153: 375380. 
Oryza, S. D. 2006. Kajian Proses Pembuatan Teh Herbal dari Campuran Teh Hijau (Camellia sinensis), Rimpang Bangle (Zingibercassumunar, Roxb), dan Daun Ceremai (Phyllanthusacidus L. Skeels). Skripsi. Fakultas Teknologi Pertanian. Institut Pertanian Bogor, Bogor.

Purwaning, A. 2010. Pengaruh Teh Kombucha (Acetobacter xylinum) Terhadap Kadar Kolesterol Tikus Putih Jantan (Rattus norvegicus). Jurnal Departemen Biologi. Universitas Muhammadiyah Malang, Malang.

Rahayu, E. S. dan K. R. Kuswanto. 1987. Teknologi Pengolahan Minuman Beralkohol. Universitas Gadjah Mada, Yogyakarta.

Rahayu, T. 2005. Kadar Kolesterol Darah Tikus Putih Setelah Pemberian Cairan Kombucha Per Oral. Jurnal Penelitian Sains dan Teknologi. Vol. 6 No. 2.

Rinihapsari, E. dan A. R. Catur. 2008. Fermentasi Kombucha dan Potensinya Sebagai Minuman Kesehatan. Media Farmasi Indonesia. Vol. 3 No. 2.

Septyaningsih, D., A. Apriyantono dan P. Sari. 2010. Analisis Sensori untuk Industri Pangan dan Agro. IPB Press. Bogor.
Silaban, M. 2005. Pengaruh Jenis Teh dan Lama Fermentasi Pada Proses Pembuatan Teh Kombucha. Skripsi. Program Studi Ilmu dan Teknologi Pangan. Fakultas Pertanian. Universitas Sumatra Utara, Medan.

Sudarmadji, S., B. Haryono dan Suhandi. 1984. Analisis untuk Bahan Makanan dan Pertanian. Edisis II. Bandung. Penerbit Alumni.

Suhardini, P. N. dan E. Zubaidah. 2015. Studi Aktivitas Antioksidan Kombucha dari Berbagai Jenis Daun Selama Fermentasi. Jurnal Pangan dan Agroindustri. Vol. 4 No. 1.

Sustrani, L., S. Alam dan I. Hadibroto. 2006. Hipertensi. PT. Gramedia Pustaka Utama : Jakarta.

Wistiana, D. dan E. Zubaidah. 2015. Karakteristik Kimiawi dan Mikrobiologis Kombucha dari Berbagai Daun Tinggi Fenol Selama Fermentasi. Jurnal Pangan Dan Agroindustri. Jurusan Teknologi Hasil Pertanian. Fakultas Teknologi Pertanian. Universitas Brawijaya, Malang.

Wood, G. R. A. and R. A. Lass. 1985. Cocoa. $4^{\text {th }}$ Ed. Fourth Edition. John Wiley and Sons, Inc. New York. 